

\section{DISCLAIMER}

This report was prepared as an account of work sponsored by an agency of the United States Government. Neither the United States Government nor any agency Thereof, nor any of their employees, makes any warranty, express or implied, or assumes any legal liability or responsibility for the accuracy, completeness, or usefulness of any information, apparatus, product, or process disclosed, or represents that its use would not infringe privately owned rights. Reference herein to any specific commercial product, process, or service by trade name, trademark, manufacturer, or otherwise does not necessarily constitute or imply its endorsement, recommendation, or favoring by the United States Government or any agency thereof. The views and opinions of authors expressed herein do not necessarily state or reflect those of the United States Government or any agency thereof. 


\section{DISCLAIMER}

Portions of this document may be illegible in electronic image products. Images are produced from the best available original document. 
Reference to a company or product name does not imply approval or recommendation of the product by Union Carbide Corporation or the Department of Energy to the exclusion of others that may meet specifications.

Printed in the United States of America. Available from National Technical Information Service

U.S. Department of Commerce

5285 Port Royal Road, Springfield, Virginia 22161

Price: Printed Copy $\$ 4.00$; Microfiche $\$ 3.00$

This report was prepared as an account of work sponsored by an agency of the United States Government. Neither the United States Government nor any agency thereof, nor any of their employees, nor any of their contractors, subcontractors, or their employees, makes any warranty, express or implied, nor assumes any legal liability or responsibility for any third party's use or the results of such use of any information, apparatus, product or process disclosed in this report, nor represents that its use by such third party would not infringe privately owned rights. 
Date of issue: March 24, 1978

Distribution Category: UC-25

\title{
CEMENTITIOUS YTTRIA PRODUCTS
}

\author{
C. E. Holcombe
}

Process Ëngineering Department

$Y-12$ Development Division

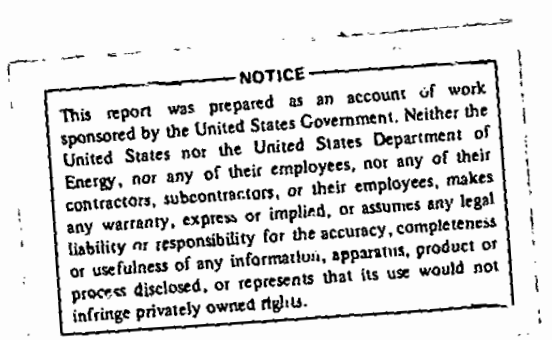

Oak Ridge $Y-12$ Plant

P. O. Box Y. Oak Ridge, Tennessee 37830

Prepared for the Department of Energy Undar US Government Cantract W-7405-eng-26 


\begin{abstract}
An investigation has been made of the physical properties and formation conditions of cements formed in the yttria/salt/water system. Cementitious binders were of the nominal $\mathrm{Y}_{2}(\mathrm{OH})_{5} \mathrm{X} \cdot \mathrm{H}_{2} \mathrm{O}$ type (where $X$ represents the $\mathrm{Cl}^{-}$or $\mathrm{NO}_{3}^{-}$). An ammonium nitrate-produced yttria cement was shown to be sinterable and was demonstrated to form very refractory castable concretes with zirconia or alumina aggregates.
\end{abstract}


CONTENTS

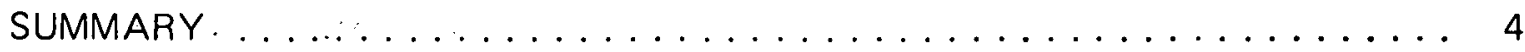

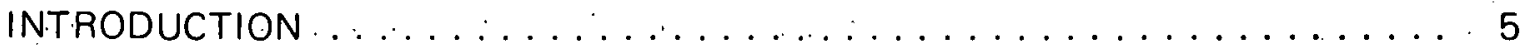

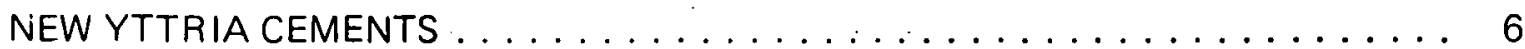

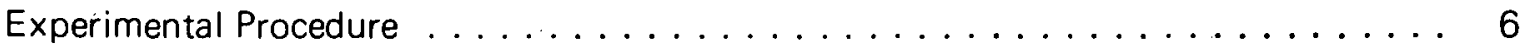

Results and Discussion ......................... 7

Neat Yttria Cements ...................... 7

Analogous Lanthanide Cements . .................... 13

Preparation of Concrete-Effects of Oxide Additives to Yttria Cement .... 13

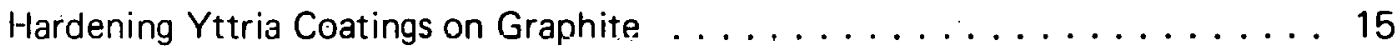

Conclusions . . . . . . . . ........................ 16

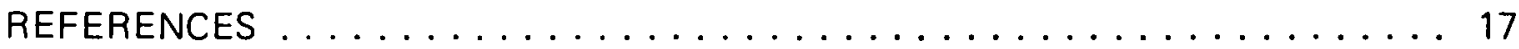




\section{SUMMARY}

Water-hardenable, yttria-based cements do not result from compositions of yttria with calcia, magnesia, or alumina. The yttria/salt/water system yielded several cement-forming systems, the best of which were with several salts $\left[\mathrm{NH}_{4} \mathrm{NO}_{3}, \mathrm{Mg}\left(\mathrm{NO}_{3}\right)_{2}, \mathrm{YCl}_{3} \cdot \mathrm{nH}_{2} \mathrm{O}\right.$ $(n=\sim 6)$, or $\mathrm{NH}_{4} \mathrm{Cl}$ ). A determination was made of the physical properties and formation conditions of these cements. Thermal and $X$-ray diffraction analyses showed the cementitious binders to be of the nominal $\mathrm{Y}_{2}(\mathrm{OH})_{5} \mathrm{X} \cdot \mathrm{H}_{2} \mathrm{O}$ type (where $X$ represents the $\mathrm{Cl}^{-}$or $\mathrm{NO}_{3}^{-}$) found for yttria plaster. The magnesium nitrate solutions appear to form a new yttrium magnesium hydroxynitrate binder phase. The ammonium nitrate-produced cements were demonstrated to be sinterable and were shown to form a castable concrete, using the zirconia or alumina aggregate.

Several lanthanide oxides $\left(\mathrm{La}_{2} \mathrm{O}_{3}, \mathrm{Nd}_{2} \mathrm{O}_{3}, \mathrm{Sm}_{2} \mathrm{O}_{3}, \mathrm{Eu}_{2} \mathrm{O}_{3}\right.$, and $\mathrm{Gd}_{2} \mathrm{O}_{3}$ ) were found to form cements with ammonium nitrate solutions. Also, painted yttria coatings on graphite crucibles could be toughened by forming salt-solution-produced cements. 


\section{INTRODUCTION}

Since an earlier study of yttria plasters ${ }^{1}$ demonstrated the hydration-binding properties possible with yttria, an effort was made(a) to prepare refractory castable cements and concretes based on yttria. Yttria cement could be used for lining or repairing furnaces or furnace parts to be contacted with reactive materials, as well as for preparing entire furnace assemblies (ie, of concrete).

The only reported 2,3 yttria-based cements were of the oxide/acid type 4 and are phosphate systems. Since yttria/acid reactions that involve concentrated acids are difficult to control and handle, this investigation was limited to yttria-based cements hardenable from water alone, or with salt solutions (similar to Surel ceiments).

Considerable literature exists on magnesium .oxychloride, ${ }^{5-8}$ illustrating that the formation of mixed oxy-(or hydroxy-) salt binder phases in the magnesia/magnesium chloride/water system produces cements. Since the first part of this study showed that hydroxy-salt binders were formed in yttria/acid/water systems, the yttria/salt/water systems were thought to be worthy of investigation for possible Sorel cement analogs. Ammonium, magnesium, or yttrium salts were selected since ammonia would evolve, magnesia would form (and would not interàct with yttria9), or yttria would result on sintering.

(a) The work described here was performed by the Development Division of the Oak Ridge Y-12 Plant. This facility is operated by the Union Carbide Corporation-Nuclear Division for the Department of Energy. 


\section{NEW YTRRIA CEMENTS}

\section{EXPERIMENTAL PROCEDURE}

Two grades of (nominally > 99.9 wt \% pure) yttria powder were used, as reported in Table 1. The most active (Type A) was used for initial studies on cement formation.

Table 1

DESIGNATION OF YTTRIA POWDERS

\begin{tabular}{cccccc}
\hline & \multicolumn{2}{c}{ Crystallite Diameter $(\mu \mathrm{m})$} & & \multicolumn{2}{c}{ Agglomerate Diameter $(\mu \mathrm{m})$} \\
\cline { 2 - 3 } Type & Mean & Range $(1)$ & & Mean & Range $(1)$ \\
\hline A(2) & 0.06 & $0.05-0.14$ & 3.45 & $1.59-7.26$ \\
$B^{(3)}$ & 7.56 & $3.51-14.95$ & & Minimal Agglomeration \\
\hline
\end{tabular}

(1) Upper limit: $90 \%$ of the particles are less than the given diameter; lower limit: $10 \%$ of the particles are less than the given diameter.

(2) Powder from the Michigan Chemical Corporation, St. Louis, Michigan. Crystallite sizes by electron microscope; agglomerate sizes by Micromerograph.

(3) Powder from the Research Chemical Corporation, Phoenix, Arizona. Crystallite sizes by Coulter Counter.

To study cement formation, enough liquid was added to the powder to ensure uniform mixing. The liquid-to-powder (or L/P) ratios (b) adequately define the compositions used. Freshly calcined (30 minutes at $\sim 600^{\circ} \mathrm{C}$ in air) powders were used. Samples were mixed in glass beakers. After mixing, the beakers were supported in a sealed bottle containing a saturated ammonium sulfate solution, which provided a curing environment with a fixed $81.1 \%$ relative humidity $(\mathrm{RH})$. Samples were inspected frequently for the first 48 hours and observed intermittently for approximately 30 days to detect any hardening tendencies during curing. At the end of this time period, samples were dried at $50-60^{\circ} \mathrm{C}$ in air for $24-48$ hours and examined by scanning electron microscopy (SEM).

For water-hardenable yttria-based cements, compositions in the $\mathrm{CaO} / \mathrm{Y}_{2} \mathrm{O}_{3}, \mathrm{MgO} / \mathrm{Y}_{2} \mathrm{O}_{3}$, $\mathrm{Al}_{2} \mathrm{O}_{3} / \mathrm{Y}_{2} \mathrm{O}_{3}$, and $\mathrm{CaO} / \mathrm{Al}_{2} \mathrm{O}_{3} / \mathrm{Y}_{2} \mathrm{O}_{3}$ systems were thought to be good candidates for cement formation. Attempts were made to prepare compounds with the following formulae: $\mathrm{CaY}_{2} \mathrm{O}_{4}, \mathrm{CaY}_{4} \mathrm{O}_{7}, \mathrm{Ca}_{3} \mathrm{Y}_{2} \mathrm{O}_{6}, \mathrm{Mg}_{3} \mathrm{Y}_{2} \mathrm{O}_{6}, \mathrm{Al}_{2} \mathrm{Y}_{4} \mathrm{O}_{9}, \mathrm{Al}_{10} \mathrm{Y}_{6} \mathrm{O}_{24}$, and $\mathrm{CaAl}_{2} \mathrm{Y}_{2} \mathrm{O}_{7}$. Reagent-grade magnesia, calcia, and aluminum nitrate nonahydrate were added to yttria in the correct molar ratios to produce the desired nominal formulae on sintering. The powder mixtures were then completely dissolved in nitric acid solutions and precipitated by adding the solution dropwise to an excess of ammonium hydroxide. After filtering and washing the precipitates with water, the mixed hydroxides were dried (50-600 $\mathrm{C}$ for $24 \mathrm{hr}$ ) and heated to $1000-1100^{\circ} \mathrm{C}$ for $4-5$ hours in alumina crucibles. Each composition was tested for cement formation in the same manner as for the yttria/salt/water samples. Depending on the sample, L/P ratios of 0.6 to 1.2 were used.

(b) L./P represents the ratio of the liquid volume in milliliters to the powder weight in grams. 
For initial yttria/salt/water studies, a salt $(c)$ solution (representing the liquid in the L/P) was prepared at a concentration fairly close to saturation (except for ammonium nitrate which has much greater solubility in water than the others tested). Concentrations are generally reported in molarity (d) since solutions could be readily prepared with that information. Approximate molarities(e) are given for the more promising salt solutions (based on the observation of the volume increase on adding the salt to water). Several salts were investigated $\left[\mathrm{NH}_{4} \mathrm{NO}_{3}, \mathrm{NH}_{4} \mathrm{Cl},\left(\mathrm{NH}_{4}\right)_{2} \mathrm{SO}_{4},\left(\mathrm{NH}_{4}\right)_{2} \mathrm{CO}_{3}, \mathrm{Mg}\left(\mathrm{NO}_{3}\right)_{2}, \mathrm{MgCl}_{2}, \mathrm{MgSO}_{4}\right.$, $\mathrm{Y}\left(\mathrm{NO}_{3}\right)_{3} \cdot \mathrm{nH}_{2} \mathrm{O}$, and $\mathrm{YCl}_{2} \cdot \mathrm{nH}_{2} \mathrm{O}$. (f)

Five lanthanide oxides $\left(\mathrm{La}_{2} \mathrm{O}_{3}, \mathrm{Nd}_{2} \mathrm{O}_{3}, \mathrm{Sm}_{2} \mathrm{O}_{3}, \mathrm{Eu}_{2} \mathrm{O}_{3}\right.$, and $\left.\mathrm{Gd}_{2} \mathrm{O}_{3}\right)$ with the system lanthanide oxide/ammonium nitrate/water were also examined for cement formation.

The characterization techniques (scanning electron microscopy, X-ray diffraction, porosimeter, and thermal analyses) were as described previously. ${ }^{1}$ Approximate time of set for these cements was qualitatively determined as the time when the surface became difficult to penetrate with a spatula blade. Relative hardness was also noted.

\section{RESULTS AND DISCUSSION}

\section{Neat Yttria Cements}

These studies on possible water-hardenable, yttria-based compositions were generally unsuccessful. The only compounds with yttria that were detected by $\dot{X}$-ray diffraction after calcining were $\mathrm{Al}_{2} \mathrm{Y}_{4} \mathrm{Og}$ (or $\mathrm{Al}_{2} \mathrm{O}_{3} \cdot 2 \mathrm{Y}_{2} \mathrm{O}_{3}$ ) and $\mathrm{Al}_{10} \mathrm{Y}_{6} \mathrm{O}_{24}$ (or $3 \mathrm{Y}_{2} \mathrm{O}_{3} \cdot 5 \mathrm{Al}_{2} \mathrm{O}_{3}$ ), with the other compositions being mixtures of the respective starting oxides. Of the samples examined, only the $3 \mathrm{MgO}-\mathrm{Y}_{2} \mathrm{O}_{3}$ showed hardening tendencies-from $\mathrm{Mg}(\mathrm{OH})_{2}$ by $X$-ra.y diffraction.

The initial screening data on cement formation in the yttria/salt/water systems are given in Table 2. The samples prepared with sulfates and $Y\left(\mathrm{NO}_{3}\right)_{3} \cdot \mathrm{nH}_{2} \mathrm{O}$, although forming cements, cracked badly on drying. The magnesium chloride sample did not set up, and the ammonium carbonate sample set up weakly, resembling chalk after drying. Several samples were set up with minimal or no cracking [formed from $\mathrm{NH}_{4} \mathrm{NO}_{3}, \mathrm{Mg}\left(\mathrm{NO}_{3}\right)_{2}, \mathrm{YCl}_{3} \cdot \mathrm{nH}_{2} \mathrm{O}$, and $\mathrm{NH}_{4} \mathrm{Cl}$ salt solutions], and were examined by $X$-ray step-scanning techniques. The $X$-ray diffraction pattern of cements produced from ammonium nitrate solution showed yttria and the nominal $\mathrm{Y}_{2}(\mathrm{OH})_{5} \mathrm{NO}_{3} \cdot \mathrm{H}_{2} \mathrm{O}$ phase reported previously. ${ }^{1}$ Also, the $X$-ray diffraction patterns of cements produced from ammonium chloride and $\mathrm{Y} \cdot \mathrm{Cl}_{3} \cdot \mathrm{nH}_{2} \mathrm{O}$ were accounted for by yttria and the nominal $\mathrm{Y}_{2}(\mathrm{OH})_{5} \mathrm{Cl} \cdot \mathrm{H}_{2} \mathrm{O}$ phase previously reported. ${ }^{1}$ From relative peak intensities, the unreacted yttria generally appeared to be the major phase for reasons

(c) Reagent-grade salts were used.

(d) Defined as moles of solute per 1000 grams of solvent (water).

(e) Defined as moles of solute per liter of solution.

(f) Where $n=\sim 6$. Salts were prepared as described previously. ${ }^{1}$ 
Table 2

SALT SOLUTIONS TESTED FOR CEMENT FORMATION WITH YTTRIA

\begin{tabular}{|c|c|c|c|c|c|c|c|}
\hline Salt $(1)$ & $\begin{array}{l}\text { Concentration } \\
\text { of Salt Solution } \\
\text { (m) }\end{array}$ & L/P Ratio (2) & $\begin{array}{l}\text { Approximate } \\
\text { Time for } \\
\text { Initial Set }\end{array}$ & $\begin{array}{c}\text { Effect of } \\
\text { Drying } \\
\text { (at } 50^{\circ} \mathrm{C} \text { for } \\
24-48 \mathrm{hrs} \text { ) }\end{array}$ & $\begin{array}{c}\text { Percent Linear } \\
\text { Drying } \\
\text { Shrinkage } \\
\text { (for } 2.25-\mathrm{cm} \\
\text { samples) }\end{array}$ & $\begin{array}{c}\text { General } \\
\text { Comments }\end{array}$ & $\begin{array}{l}\text { Scanning Electron } \\
\text { Microscopy } \\
\text { Observations }(3)\end{array}$ \\
\hline $\mathrm{NH}_{4} \mathrm{NO}_{3}$ & 13.9 & 0.6 & $<48 \mathrm{Hr}$ & No Cracks & $\sim 0$ & Very hard after drying. & $\begin{array}{l}0.75-1.75 \mu \mathrm{m} \text { plates and needles present } \\
\text { as the bonding phase. }\end{array}$ \\
\hline $\mathrm{NH}_{4} \mathrm{Cl}$ & 6.9 & 0.75 & $\sim 4 W k$ & No Cracks & $\sim 5$ & $\begin{array}{l}\text { Weakly set, but becomes very } \\
\text { hard on drying. }\end{array}$ & $\begin{array}{l}0.25 \cdot 1 \mu \mathrm{m} \text { plates and needles as the } \\
\text { bonding phase. }\end{array}$ \\
\hline$\left(\mathrm{NH}_{4}\right)_{2} \mathrm{SO}_{4}$ & 5.5 & 0.6 & $<48 \mathrm{Hr}$ & Cracked & - & - & 2.5 - $10 \mu \mathrm{m}$ chunky particles. \\
\hline$\left(\mathrm{NH}_{4}\right)_{2} \mathrm{CO}_{3}$ & 5.5 & 0.75 & $\sim 4 W k$ & No Cracks & $\sim 0$ & Weakly set; resembles chalk. & $0.5-2 \mu \mathrm{m}$ needles as the bonding phase. \\
\hline $\mathrm{Mg}\left(\mathrm{NO}_{3}\right)_{2}$ & 4.4 & 0.6 & $<1 W k$ & $\begin{array}{l}\text { Few Cracks } \\
\text { on Top }\end{array}$ & $\sim 4$ & Very hard after drying. & 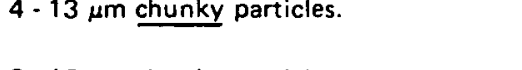 \\
\hline $\mathrm{MgCl}_{2}$ & 2.7 & 0.75 & No Set & & $\cdot$ & Not hard after drying. & 3-12 $\mu \mathrm{m}$ chunky particles. \\
\hline $\mathrm{MgSO}_{4}$ & 3.5 & 0.8 & $<2 W k$ & Cracked & - & $\cdot$ & $2.5-7.5 \mu \mathrm{m}$ chunky particles. \\
\hline $\mathrm{Y}\left(\mathrm{NO}_{3}\right)_{3} \cdot \mathrm{nH}_{2} \mathrm{O}$ & $1.4\left(\begin{array}{c}\text { based on } \\
n=6\end{array}\right)$ & 0.8 & $<1 \mathrm{Wk}$ & Badly Cracked & - & $\begin{array}{l}\text { Cracked before drying after } \\
\sim 1 \text { wk. }\end{array}$ & $\begin{array}{l}1.25-3.4 \mu \mathrm{m} \text { plates and needles as the } \\
\text { bonding phase. }\end{array}$ \\
\hline $\mathrm{YCl}_{3} \cdot \mathrm{nH}_{2} \mathrm{O}$ & $1.3\left(\begin{array}{c}\text { based on } \\
n=6\end{array}\right)$ & 0.65 & $<48 \mathrm{Hr}$ & No Cracks & $\sim 0$ & $\begin{array}{l}\text { Hardening begins at } \sim 1 \mathrm{hr} ; \\
\text { very hard after drying. }\end{array}$ & $\begin{array}{l}0.25-0.75 \mu \mathrm{m} \text { plates and needles as the } \\
\text { bonding phase. }\end{array}$ \\
\hline
\end{tabular}

(1) Conditions after blending with $\mathrm{Y}_{2} \mathrm{O}_{3}$ powder (Type $\mathrm{A}$ ) and exposing to a $81.1 \%$ relative humidity [from a saturated $\left(\mathrm{NH}_{4}\right)_{2} \mathrm{SO}_{4}$ solution] .

(2) Liquid volume (in $\mathrm{cm}^{3}$ )/powder weight (iri grams).

(3) Dimensions are diameter (for plates), lengths (for needles), or largest dimension (for particles). These are approximate ranges; primary shape of particles is underlined. 
discussed before. ${ }^{1}$ The $X$-ray diffraction pattern of the cement prepared from magnesium nitrate is shown in Table 3 and represents an unidentified binder material-probably a yttrium magnesium hydroxynitrate, since no free magnesium nitrate was detected.

The physical properties of dried yttriabased cements are reported in Tables 4 and 5 . The measured porosity values are much lower than for plasters (generally 50 to $65 \%$ ), and were regularly less than $50 \%$. The relative hardnesses of these cements paralleled the porosity trends. Although magnesium nitrate-produced cements were quite hard, they always cracked on drying (for $\sim 13$-mm-thick samples). For concrete, where only a thin cementitious layer is required between inert aggregates, the magnesium nitrate-produced cements may be used without cracking occurring.

Table 5 also illustrates the effect of varying the ammonium nitrate concentration and the yttria particle size. For an $L / P=0.7$. a theoretical concentration of 6.3 molar $(\mathrm{M})$ would give complete conversion to the nominal binder phase composition: $\mathrm{Y}_{2}(\mathrm{OH})_{5} \mathrm{NO}_{3} \cdot \mathrm{H}_{2} \mathrm{O}$. However, an $\sim 8.5-\underline{M}$ solution of ammonium nitrate yielded only $87 \%$ conversion to the binder phase. It is suspected that the degree of binder formation depends on
Table 3

$X$-RAY DIFFRACTION PATTERN OF CEMENT FORMED BY THE ADDITION OF MAGNESIUM NITRATE SOLUTION (4.4 m) TO YTTRIA POWDER

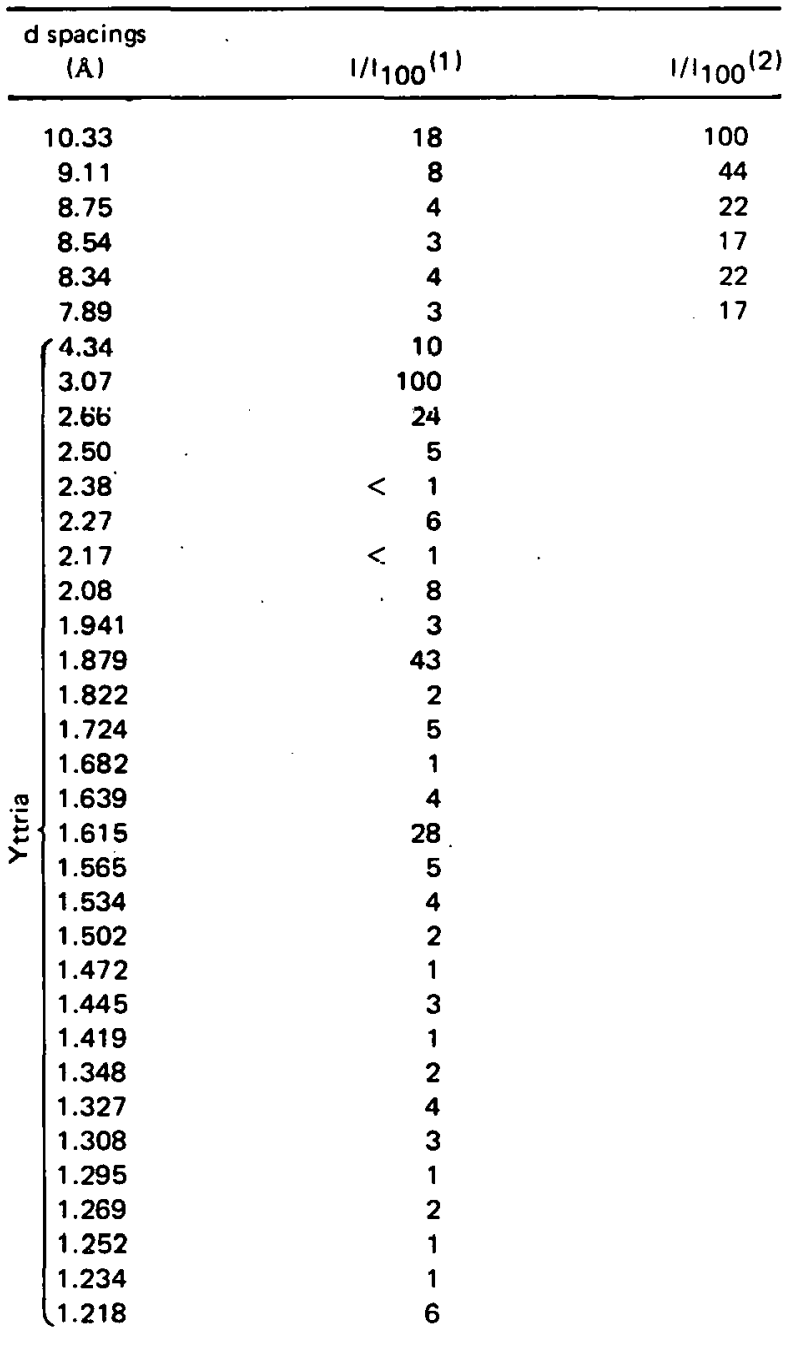

(1) Peak-height intensities, diffractometer, copper $\mathrm{K} \alpha_{\alpha}$ radiation.

(2) Excluding vttria spacings.

the difference between the initial concentration of the salt in solution and a final equilibrium concentration of the salt in solution. For this reason, excess ammonium nitrate (over the theoretical required to form the hydroxynitrate binder) is beneficial in yielding a higher percentage of the binder phase in the cement. The physical-property variation with salt-solution concentration is further illustrated in Figure 1. From Table 5 and Figure 1, a concentration of 13.9 molal $(\underline{m})$ seems to provide a good balance between excess ammonium nitrate and porosity of the dried cement.

The ammonium nitrate concentration may fall in the range of 0.7 to $23.3 \underline{M}$. If the concentration is $\leqslant 0.4 \underline{\mathrm{M}}$; the cement will not set up. At $23.3 \underline{\mathrm{m}}$, the liquid phase is 
Table 4

PHYSICAL PROPERTIES OF SOME NEAT YTTRIA CEMENTS PREPARED WITH SALT SOLUTIONS

\begin{tabular}{|c|c|c|c|c|c|c|c|c|c|}
\hline Salt $(1,2)$ & $\begin{array}{l}\text { Concentration } \\
\text { of Salt } \\
\text { Solution (3) } \\
\text { (m) }\end{array}$ & $\begin{array}{l}\text { Powder } \\
\text { Type (4) }\end{array}$ & $\begin{array}{c}\text { Bulk } \\
\text { Density } \\
\left(\mathrm{g} / \mathrm{cm}^{3}\right)\end{array}$ & $\begin{array}{l}\text { Apparent } \\
\text { Specific } \\
\text { Gravity }\end{array}$ & $\begin{array}{c}\text { Porosity } \\
(\%)\end{array}$ & $\begin{array}{c}\text { Surface } \\
\text { Area } \\
\left(\mathrm{m}^{2} / \mathrm{g}\right)\end{array}$ & $\begin{array}{l}\text { Average } \\
\text { Pore } \\
\text { Diameter } \\
(\mu \mathrm{m})\end{array}$ & $\begin{array}{c}\text { Percentage } \\
\text { of Pores } \\
\text { Less Than } \\
10 \text { m Diameter } \\
\quad \text { (\%) }\end{array}$ & $\begin{array}{l}\text { Total Percentage } \\
\text { Weight Lost on } \\
\text { Heating to } 1500^{\circ} \mathrm{C} \\
\text { in Argon }(5) \\
(\%)\end{array}$ \\
\hline $\mathrm{NH}_{4} \mathrm{Cl}$ & $6.9[\sim 4.6]$ & A & 1.89 & 3.03 & 37.7 & 23.6 & 0.3 & 99.3 & 29.5 \\
\hline $\mathrm{Mg}\left(\mathrm{NO}_{3}\right)_{2}$ & $4.4[\sim 3.7]$ & A & 2.48 & 3.19 & 22.1 . & 0.5 & 3.1 & 95.2 & 27.5 \\
\hline $\mathrm{Mg}\left(\mathrm{NO}_{3}\right)_{2}$ & $4.4[\sim 3.7]$ & B & 2.19 & 3.36 & 34.9 & 0.5 & 2.2 & 99.0 & \\
\hline $\mathrm{YCl}_{3} \cdot \mathrm{nH}_{2} \mathrm{O}[\mathrm{n}=\sim 6]$ & $1.3[\sim 1.2]$ & A & 1.62 & 3.16 & 48.7 & 45.0 & 0.2 & 99.7 & 23.5 \\
\hline
\end{tabular}

(1) Cements prepared with $L / P=0.6-0.75$, cured 30 days, dried.

(2) Properties determined with mercury intrusion porosimeter.

(3) Approximate molarities shown in brackets.

(4) See Table 1 for identification.

(5) By thermogravimetric analyses. 
Table 5

COMPARISON OF NEAT YTTRIA CEMENTS PREPARED WITH DIFFERENT AMMONIUM NITRATE CONCENTRATIONS AND PARTICLE SIZES

\begin{tabular}{lccccccc}
\hline $\begin{array}{c}\text { Concentration } \\
\text { of } \mathrm{NH}_{4} \mathrm{NO}_{3}(1,2) \\
(\underline{\mathrm{m}})\end{array}$ & $\begin{array}{c}\text { Bulk } \\
\text { Powder } \\
\text { Type (3) }\end{array}$ & $\begin{array}{c}\text { Apparent } \\
\text { Density } \\
\left(\mathrm{g} / \mathrm{cm}^{3}\right)\end{array}$ & $\begin{array}{c}\text { Specific } \\
\text { Gravity }\end{array}$ & $\begin{array}{c}\text { Porosity } \\
(\%)\end{array}$ & $\begin{array}{c}\text { Surface } \\
\text { Area } \\
\left(\mathrm{m}^{2} / \mathrm{g}\right)\end{array}$ & $\begin{array}{c}\text { Average } \\
\text { Pore } \\
\text { Diameter } \\
(\mu \mathrm{m})\end{array}$ & $\begin{array}{c}\text { Percentage } \\
\text { of Pores } \\
\text { Less Than } \\
10 \mu \mathrm{m} \text { Diameter }\end{array}$ \\
\hline 3.1 & B & 1.41 & 3.19 & 55.7 & 18.7 & 0.9 & 98.8 \\
12.5 & B & 1.77 & 3.08 & 42.5 & 14.8 & 1.0 & 97.6 \\
$13.9[\sim 8.5](4)$ & B & 1.84 & 2.95 & 37.6 & 11.4 & 0.8 & 99.1 \\
$23.3(5)$ & B & 1.95 & 2.71 & 27.9 & 5.0 & 0.2 & 99.8 \\
13.9 & A & 1.94 & 2.79 & 30.4 & 15.9 & 0.1 & 100.0 \\
$23.3(5)$ & A & 1.97 & 2.81 & 29.7 & 7.5 & 1.1 & 97.7 \\
\hline
\end{tabular}

(1) Cements prepared with an $L / P=0.7$, cured 30 days, dried.

(2) Properties determined by mercury intrusion porosimeter.

(3) See Table 1 for identification.

(4) Specimen analyzed by quantitative $X$-ray diffraction analysis showed $13 \pm 3 \mathrm{wt} \%$ free yttria; by thermogravimetric analysis, $33.8 \mathrm{wt} \%$ lost on heating to $1500^{\circ} \mathrm{C}$ in argon; approximate molarity shown in brackets.

(5) Saturated solution; molarity shown represents solubility at $21.1^{\circ} \mathrm{C}$. The solubility varies [ie, from $22.7 \mathrm{~m}\left(20^{\circ} \mathrm{C}\right)$ to $\left.24.0 \mathrm{~m}\left(22.2^{\circ} \mathrm{C}\right)\right]$ with room temperature.

saturated and causes setting, but is rather difficult to handle because of the excess ammonium nitrate. The L/P ratio generally used for yttria cement was 0.6 to 0.8 . If excess liquid is used, the cement sets up under the excess liquid; if too little is used, a stiff, nonworkable paste results. Generally, the lower L/P. limit appears to be $\sim 0.5$.

The mechanism of cement formation is probably very similar to that suggested for plaster formation. The major difference appears to be kinetics. Use of salt solutions appears to slow down the rate of formation of the binder-phase crystals (generally needles or plates) in such a fashion that a much greater packing density occurs, giving rise to the low-porosity, hard cements. It should be noted that, regarding both plasters and cements, yttria is never completely converted to the hydroxy-salt binder. Therefore, the neat $(\mathrm{g})$ cements are really concretes with the residual unreacted yttria acting as an aggregate.

Simultaneous differential thermal analysis/thermal gravimetric analysis (DTA/TGA) in flowing argon and complementary thermogravimetric (TG)-quad analyses [at a pressure of $<10^{-4}$ torr $\left.\left(<1.33 \times 10^{-2} \mathrm{~Pa}\right)\right]$ were undertaken to $1000^{\circ} \mathrm{C}$ for each of these cements [prepared from $\mathrm{NH}_{4} \mathrm{NO}_{3}, \mathrm{Mg}\left(\mathrm{NO}_{3}\right)_{2}, \mathrm{YCl}_{3} \cdot \mathrm{nH}_{2} \mathrm{O}$, and $\mathrm{NH}_{4} \mathrm{Cl}$ ]. The decomposition processes and thermal effects for the ammonium nitrate-produced cement are identical to those previously discussed ${ }^{1}$ for nitric acid-produced plaster and yttrium hydroxynitrate hydrate binder phase, with the exception that some evolution of the $\mathrm{N}-\mathrm{H}-\mathrm{O}$ species $\left(\mathrm{NH}_{3}\right.$, $\mathrm{N}_{2}, \mathrm{NO}, \mathrm{N}_{2} \mathrm{O}, \mathrm{NO}_{2}$ ) below $200^{\circ} \mathrm{C}$ occurred from excess ammonium nitrate. [The TG-quad analysis of pure ammonium nitrate indicated that it decomposes completely by the time a temperature of $160^{\circ} \mathrm{C}$ is r eachied.]

(g) The term "neat" refers to materials having a zero aggregate content. 


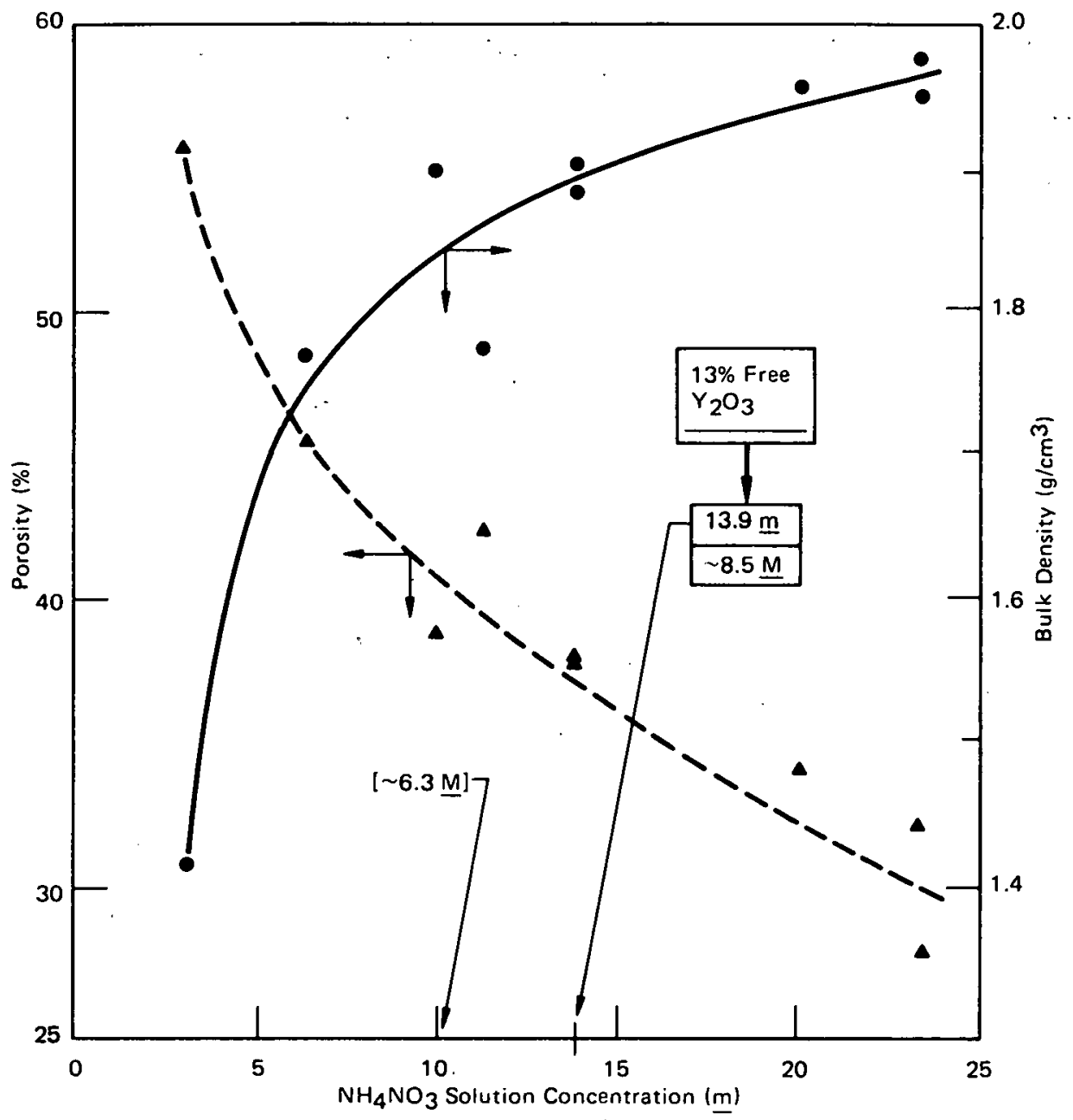

Note: Data from samples used in Table 5 plus additional samples prepared in the same manner.

Figure 1. VARIATION IN THE PHYSICAL PROPERTIES OF AMMONIUM NITRATEPRODUCED CEMENT WITH CONCENTRATION OF THE SALT SOLUTION. [Cements Prepared with an $L / P=0.7$ (Type B powder), Cured for 30 Days, then Dried]

Thermal analyses of the yttrium chloride hexahydrate and ammonium chloride-produced cements matched those reported previously ${ }^{1}$ for yttrium hydroxychloride hydrate binder phases in argon. No ammonia was detected by TG-quad, since no excess ammonium chloride was used over the theoretical for forming the binder.

The DTA/TGA curves for magnesium nitrate-produced cements further pointed out that a discrete new phase had formed since they did not match the DTA data for the hydroxynitrate binder. Figure 2, Graphs $a$ and $b$, illustrate its decomposition behavior to $1000^{\circ} \mathrm{C}$. No additional thermal effects occurred to $1500^{\circ} \mathrm{C}$. The TG-quad study to $1000^{\circ} \mathrm{C}$ showed that only water evolved below $350^{\circ} \mathrm{C}$; above $350^{\circ} \mathrm{C}, \mathrm{N}-\mathrm{O}$ species ( $\mathrm{NO}, \mathrm{N}_{2} \mathrm{O}, \mathrm{NO}_{2}$ ) were liberated. This result establishes that endotherms below $350^{\circ} \mathrm{C}$ arise from dehydration. Since TG-quad data were taken in vacuum, species generally evolve at somewhat lower temperatures than would result in argon; thus, both endotherms observed in argon above $350^{\circ} \mathrm{C}$ may occur from $\mathrm{N}-\mathrm{O}$ species, or only the higher-temperature endotherm could result 
from evolution of $\mathrm{N}-\mathrm{O}$ species as for yttrium hydroxynitrate binder. The higher-temperature endotherm (beginning at $\sim 473^{\circ} \mathrm{C}$ ) peaks at a point similar to that for yttrium hydroxynitrate binder, probably since these nitrate phases appear to be unstable above $600^{\circ} \mathrm{C}$.

Thermal analyses indicated that the nitrate cements could be sintered if a sufficiently slow heating rate was used below $600^{\circ} \mathrm{C}$. The chloride cements, from thermal data, could be sintered in air (because of replacement of the chlorine with oxygen discussed before ${ }^{1}$ ), but sintering in argon would be hampered by rapid yttrium oxychloride evolution above $1400^{\circ} \mathrm{C}$ (after structural development has taken place). Sintering the cement produced from a magnesium nitrate salt solution would result in a mixture of yttria and magnesia 9 which could have a relatively high expansion coefficient-the weighted average of yttria $\left(\sim 8 \times 10^{-6 / 0} \mathrm{C}\right.$, to $\left.1000^{\circ} \mathrm{C}\right)$ and magnesia $\left(\sim 14 \times 10^{-6 / 0} \mathrm{C}\right.$, to $\left.1000^{\circ} \mathrm{C}\right)$ phases. For some applications for matching the expansive behavior of substrates, the maynesium nitrate-produced yttria cement may be advantageous. One decisive advantage of yttria cements over conventional castable cements (ie, calcium aluminates) is that yttria cements are not subject to rehydration after sintering.

The physical properties of neat ammonium nitrate-produced yttria cement before and after sintering ( $\sim 0.6-\mathrm{cm}$-thick specimens) are reported in Table 6 . Figure 3 illustrates the microstructural changes that result from sintering. The data indicate that the bulk-density values before and after sintering are considerably higher (and the porosities considerably lower) than yttria plaster. Yttria cement is about 40 to $50 \%$ more dense than the plaster. The acicular (needlelike) or lenticular (platelike) crystals appear to be quite compact in View a of Figure 3, and little resemblance of the original structure remains at $1350^{\circ} \mathrm{C}$ (View b). However, other than denseness of the particle packing, the morphology of the yttria cement on sintering parallels that of yttria plaster.

\section{Analogous Lanthanide Cements}

The hydroxychloride and hydroxynitrate binder phases, as shown for yttria plasters, would be expected to exist for the rare-earth oxides. Thus, a study was made of the behavior of those oxide powders already discussed ( $\mathrm{La}_{2} \mathrm{O}_{3}, \mathrm{Nd}_{2} \mathrm{O}_{3}, \mathrm{Sm}_{2} \mathrm{O}_{3}, \mathrm{Eu}_{2} \mathrm{O}_{3}$, and $\mathrm{Gd}_{2} \mathrm{O}_{3}$ ) with ammonium nitrate solutions. The physical properties of these neat cements are given in Table 7. The cements tested had similar properties except lanthania which expanded on curing and (by SEM) formed very large particles (typically, $5 \mu \mathrm{m}$ long by 1 to $2 \mu \mathrm{m}$ wide)-primarily appearing as multiple plates bonded into a needle shape.

\section{Preparation of Concrete-Effects of Oxide Additives to Yttria Cement}

Preparation of a castable concrete based on yttria has the advantage of allowing the formation of a thin cement (or binder phase) layer between the aggregate particles, aiding sinterability (without cracking), and allowing the properties of the composite to be tailored for specific needs. The effects of aggregates were tested by using $80 \mathrm{wt} \%$ aggregate and 20 wt $\%$ yttria with a $13.9-\underline{m}$ ammonium nitrate solution ( $L / P \leqslant 0.2$, generally). Or several 


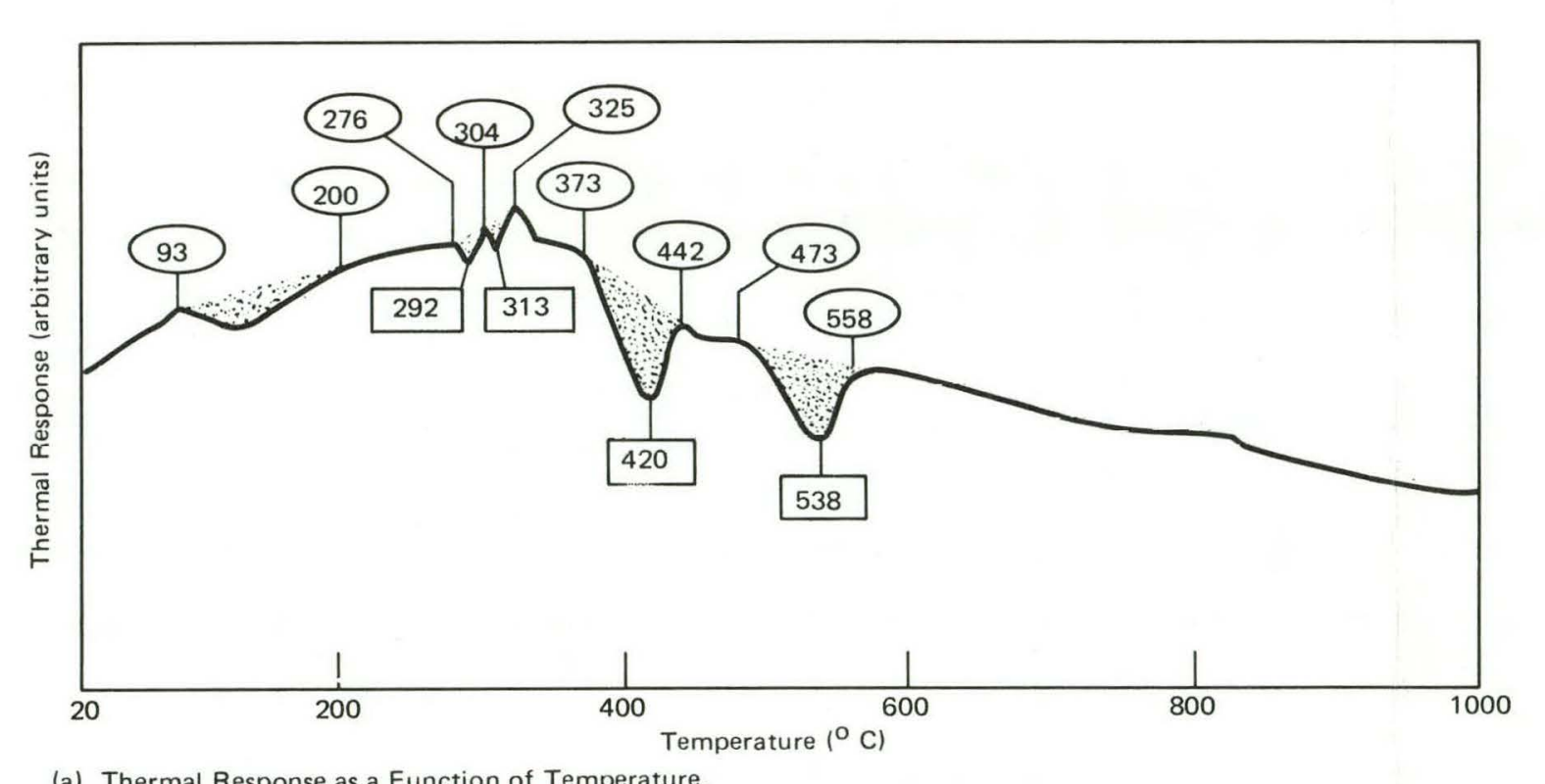

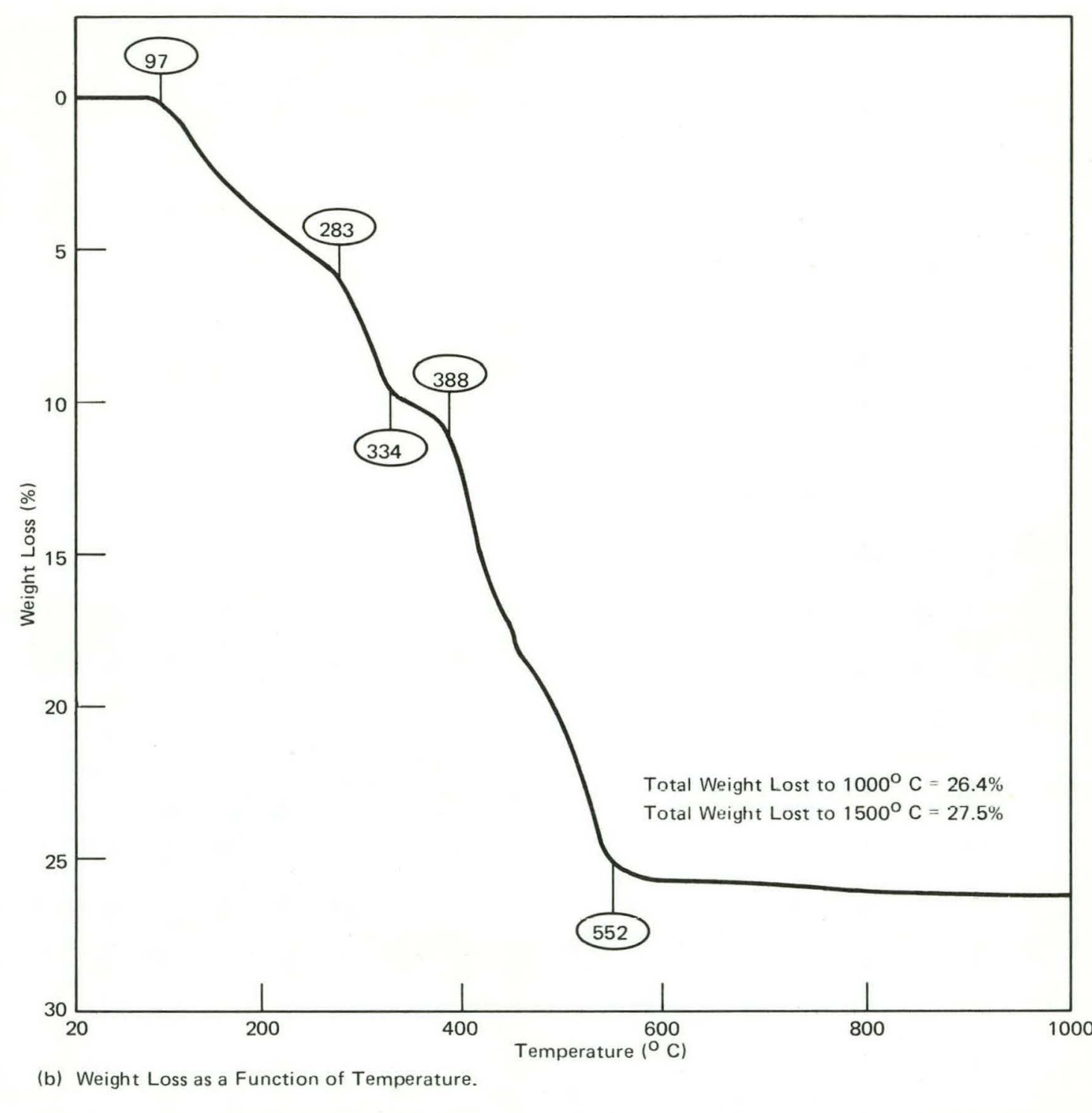

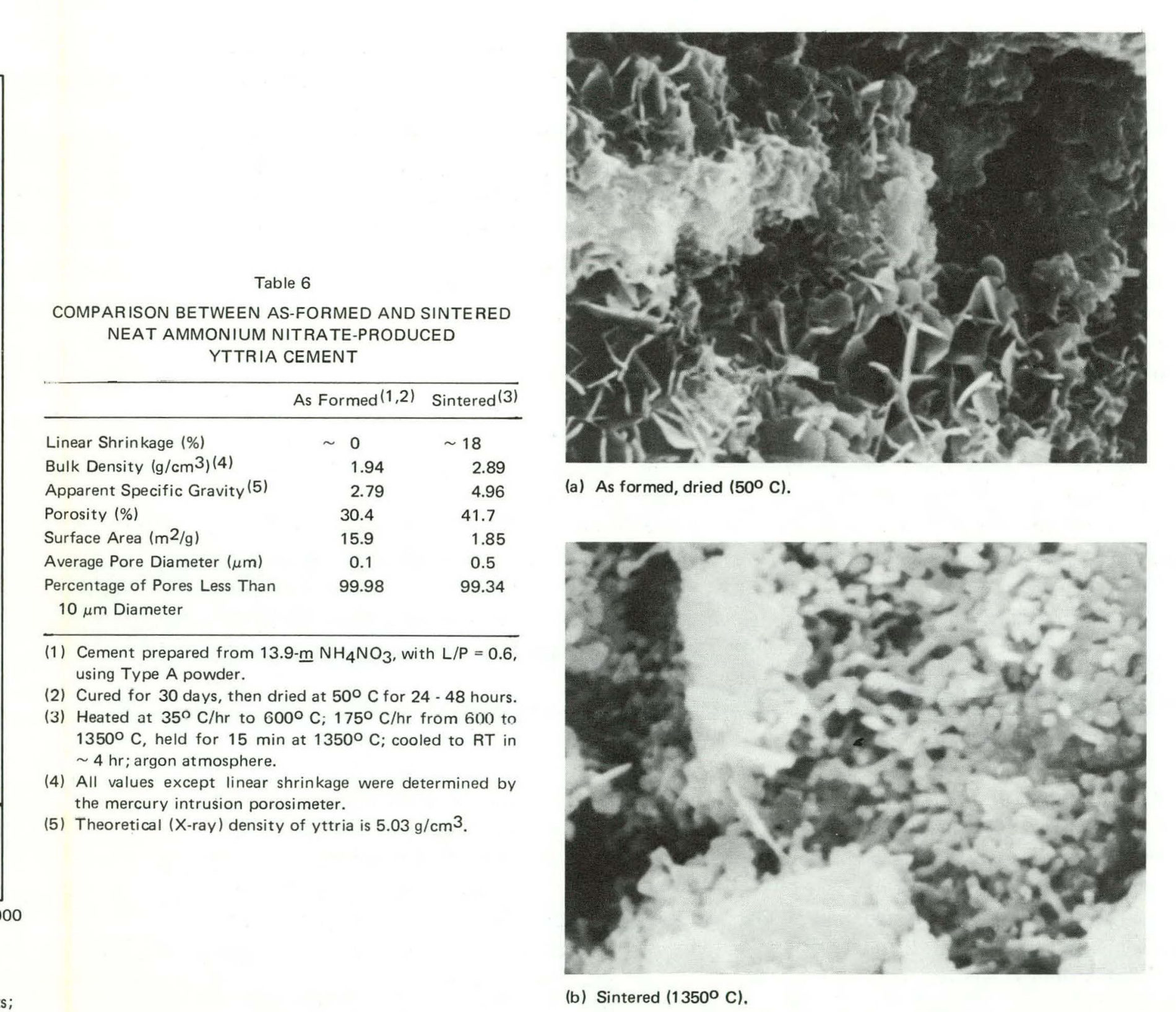

(b) Sintered $\left(1350^{\circ} \mathrm{C}\right.$.

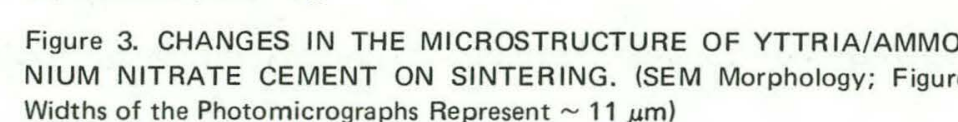


Table 7

PHYSICAL PROPERTIES OF NEAT LANTHANIDE CEMENTS

\begin{tabular}{|c|c|c|c|c|c|c|}
\hline \multirow[b]{2}{*}{ Property (1.2) } & \multicolumn{5}{|c|}{ Starting Oxide (3) } & \multirow[b]{2}{*}{ Comments } \\
\hline & $\mathrm{La}_{2} \mathrm{O}_{3}(4)$ & $\mathrm{Nd}_{2} \mathrm{O}_{3}$ & $\mathrm{Sm}_{2} \mathrm{O}_{3}$ & $\mathrm{Eu}_{2} \mathrm{O}_{3}$ & $\mathrm{Gd}_{2} \mathrm{O}_{3}$ & \\
\hline Hardness Rank $(5)$ & 5 & 1 & 4 & 2 & 3 & No cracking was observed \\
\hline $\begin{array}{l}\text { Approximate Time for } \\
\text { Initial Set }\end{array}$ & $<24 \mathrm{hr}$ & $<48 \mathrm{hr}$ & $<2 w k$ & $<48 \mathrm{hr}$ & $<48 \mathrm{hr}$ & $\begin{array}{l}\text { during curing or after } \\
\text { drying. Drying shrinkage }\end{array}$ \\
\hline Bulk Density $\left(\mathrm{g} / \mathrm{cm}^{3}\right)$ & 1.43 & 1.82 & 1.87 & 1.80 & 1.80 & was $\sim 0$ for $2.25-\mathrm{cm}$ \\
\hline Apparent Specific Gravity & 3.09 & 3.46 & 3.45 & 3.37 & 3.51 & samples. Each oxide \\
\hline Porosity (\%) & 53.8 & 47.4 & 45.8 & 46.6 & 48.7 & appeared to begin \\
\hline Surface Area $\left(\mathrm{m}^{2} / \mathrm{g}\right)$ & 3.6 & 11.0 & 5.6 & 11.3 & 12.6 & reacting shortly after \\
\hline Average Pore Diameter $(\mu \mathrm{m})$ & 1.9 & 0.3 & 1.4 & 0.4 & 0.7 & mixing, since some \\
\hline $\begin{array}{l}\text { Percentage of Pores Less } \\
\text { Than } 10 \mu \mathrm{m} \text { Diameter }\end{array}$ & 98̈.3 & 99.5 & 99.0 & 88.6 & 991 & $\begin{array}{l}\text { ammonia evolved and } \\
\text { heating occurred. }\end{array}$ \\
\hline
\end{tabular}

(1) Cements prepared from 13.9- $\mathrm{m} \mathrm{NH}_{4} \mathrm{NO}_{3}$ with $\mathrm{L} / \mathrm{P}=0.8$; cured 30 days.

(2) Properties determined by mercury intrusion porosimeter with dried (50-600 C, 24 - $48 \mathrm{hr}$ ) samples.

(3) Nominally $<500$ mesh (or $<25 \mu \mathrm{m}$ ) and $>99 \mathrm{wt} \%$ pure.

(4) Cement expanded during drying, breaking the glass container after five days.

(5) Determined before and after drying. Ranks 1 - 3 are quite hard; Ranks 4 and 5 are moderately hard.

aggregates $\left(\mathrm{Al}_{2} \mathrm{O}_{3}, \mathrm{SiC}, \mathrm{MgO}\right.$, and $\mathrm{CaO}$-stabilized $\mathrm{ZrO}_{2}$; nominally $-14+325$ mesh or $-1410+44 \mu \mathrm{m}$ particle size), zirconia allowed the formation of the hardest, tough concrete, setting in 24-72 hours. This material appeared to become harder on drying at $50^{\circ} \mathrm{C}$ for 24 hours. However, after about two days of an additional exposure to air ( 50\% RH) at room temperature, the strength of the concrete deteriorated. Examination by the SEM showed that the needle (or plate)-like phase was bonding to the zirconia particles, but microcracking had resulted (presumably from rehydration). Thus, this concrete should be sintered as soon as possible after initial drying to prevent microcracking.

The alumina aggregate formed a weaker concrete than zirconia. Aggregates of silicon carbide yielded a relatively weak concrete (possibly becausc of the aggregate-to-yttria ratio of 4 to 1). The magnesia aggregate prevented setting, although some strength developed on drying.

Crucibles ( $\sim 5^{\prime \prime} \mathrm{D} x \sim 5^{\prime \prime} \mathrm{H}$, with $\sim 0.5^{\prime \prime}$ walls) of 20 wt $\%$ yttria/80 wt $\%$ aggregate were prepared with a $13.9-\mathrm{m}$ ammonium nitrate solution. Both zirconia and alumina were used as aggregates. After curing ( $36 \mathrm{hr}$ in $100 \% \mathrm{RH}$ ) and drying $\left(50^{\circ} \mathrm{C}, 15 \mathrm{hr}\right.$ ), the crucibles were sintered in vacuum $\left(1.33 \times 10^{-2} \mathrm{~Pa}\right)-y$ ttria/alumina at $1600^{\circ} \mathrm{C}$ for $2 \mathrm{hr}$; yttria/zirconia at $1950^{\circ} \mathrm{C}$ for $1 \mathrm{hr}$. Heating rates of $100^{\circ} \mathrm{C} / \mathrm{hr}$ to $600^{\circ} \mathrm{C}$ were used to allow volatile material from the hydroxysalt binder phase to escape without cracking the crucibles. Above $600^{\circ} \mathrm{C}$ and for cooldown, rates of $250-400^{\circ} \mathrm{C} / \mathrm{hr}$ were used. Using these procedures, tough, well-sintered, yttria-based concrete crucibles resulted.

\section{Hardening Yttria Coatings on Graphite:}

Yttria-paint protective coatings for graphite crucibles have been previously developed, using a $3 \%$ sodium carboxymethylcellulose $(\mathrm{CMC})$ solution ${ }^{10}$ as the suspension agent, binder, and sintering aid. Generally, L/P ratios of 1.0 to 1.9 were used. Since the yttria/salt/water-type 
cements set fairly slowly (compared to yttria plasters), consideration was given to the possibility of toughening the coatings for preventing or reducing flaws resulting from crucible-loading operations. It was found that these brush-applied coatings may be hardened by: (1) spraying the finished coating with a dilute ammonium nitrate solution, such as $0.7 \mathrm{~m}$ (the lower initial concentrations are favored, since the final concentration increases on drying), or (2) adding ammonium nitrate to the $3 \% \mathrm{CMC}$ solution, followed by mixing the paint normally $\left[\leqslant 0.7 \underline{\mathrm{m}} \mathrm{NH}_{4} \mathrm{NO}_{3}\right.$ works well; lower concentrations permit longer handling times (pot life) of the paint before setting commences] The coatings must then be cured for about 7 - 10 days in normal room air $(\sim 50 \% \mathrm{RH})$ to achieve the maximum benefit to the unsintered coating (paint) on graphite. The curing time of up to 10 days in room air was found necessary for other ammonium nitrate-produced yttria cements, as compared to the 24 - 48-hour time span for adequate curing in an $81.1 \% \mathrm{RH}$ environment.

\section{CONCLUSIONS}

A new cement can be formed from the simple reaction of yttria powder with salt solutions. The cement has porosities in the range of 20 - 50\% (typically $30-40 \%$ ), which is 25 to $60 \%$ lower in porosity than for acid-produced yttria plasters. Sinterable concretes may be prepared with alumina (usable to $\sim 1650^{\circ} \mathrm{C}$ ) or zirconia (usable to $\sim 2000^{\circ} \mathrm{C}$ ) aggregates, with the latter forming a concrete which can be used about $400^{\circ} \mathrm{C}$ above the maximum use temperature of calcium aluminate-based concretes. Thus, yttria-based concretes are not subject to rehydration, and (since only $\sim 20$ wt \% is used for the cementitious yttria constituent) provides a relatively inexpensive, high-temperature castable that is applicable for many structural uses (eg, crucibles and supports) in reactive environments. The yttria/zirconia composition should be useful for high-temperature corrosive environments (ie, magnetohydrodynamic generator applications). 


\section{REFERENCES}

1. Holcombe, C. E., Edwards, C. C., and Carpenter, D. A.; New Yttria Plasters, Y-2104; Union Carbide Corporation-Nuclear Division, Oak Ridge Y-12 Plant, Oak Ridge, Tennessee; January 17, 1978.

2. Kingery, W. D.; "II, Cold-Setting Properties", J Amer Ceram Soc, 33, (8), pp 242 - 247 (1950).

3. Golynko-Vol'fson, S. L. and Sudakas, L. G.; "Some Principles of the Appearance of Binding Properties in Phosphate Systems", J Applied Chem (Russian translation), 38, (7), pp 1441 - 1445 (1965).

4. Federov, N. F.; "Cements Based on Systems of the Metal Oxide-Acid Type", J Applied Chem (Russian translation), 41, (12), pp 2591 - 2592 (1968).

5. Sorrell, C. A. and Armstrong, C. R.; "Reaction and Equilibria in Magnesium Oxychloride Cements", J Amer Ceram Soc, 59, (1 - 2), pp 51 - 54 (1976).

6. Solov'eva, E. S., Smirnov, B. I., Segalova, E. E., and Rebinder, P. A.; "Physicochemical Characteristics of Hardening of Magnesium Oxychloride Cement: The Kinetics of Formation of Disperse Hardening Structures by the Interaction of Magnesium Oxide with Magnesium Chloride in an Aqueous Medium", Colloid J (Russian translation), 30, (5), pp $570-574$ (1968).

7. Harper, F. C.; "Effect of Calcination Temperature on the Properties of Magnesium Oxides for Use in Magnesium Oxychloride Cements", J Appl Chem (London), 17, (1), pp 5 - 10 (1967).

8. Kacker, K. P., Mehrotra, G. S., and Rai, M.; "Petrographic and Thermal Evaluation of Dolomites for the Manufacture of Magnesium Oxychloride Cement", J App/ Chem (London), 20, (6), pp $189-193$ (1970).

9. Tresvyatskii, S. G., Lopato, L. M., Ggorodnikova, A. A., and Shevchenko, A. V.; "Phase Diagrams of the Systems Formed by Yttrium, Erbium, and Ytterbium Oxides with Magnesium Oxide", Inorg Mat/s (Russian translation), 7, (11), pp 1798 - 1801 (1972).

10. Koger, J. W., Holcombe, C. E., and Banker, J. G.; "Coatings on Graphite Crucibles Used in Melting Uranium", Thin Solid Films, 39, (3), pp 297 - 303 (1976). 


\section{Distribution}

Air Force Materials Laboratory Wright Patterson

Mazdiyasni, K. S:

Department of Energy - Albuquerque

Vespe, V. C.

Department of Energy - DMA-Washington

Hagedorn, Z., Lt Col

Department of Energy - Oak Ridge

Hickman, H. D.

Reed, R. E.

Zachry, D. S., Jr

Lawrence Livermore Laboratory

Broadman, G. A./Hanson, E. R.

Crowley, W. B.

Gamble, D. P.

Hodges, A. J./Price, P. N:

Hoenig, C.

Kane, J. S.

Nelson, W. E:

Otsuki, H. H:

Reynolds, H. L:/Kury, J. $H$.

Rizzo, H. F.Milson, H. D.

Technical Information Division

Los Alamos Scientific Laboratory

Baker, R. D:

Byers, D.

Deinken, H. P.

Eyster, E. H.

Fuller, J. C.

Gac, F.

Horpedahl, L.

Hoyt, H. C:

Library Services

Olwin, R. B:

Plassmann, E. H.

Shafer, B. P.

Shreffler, R. G.

Skaggs, S, R.

Stoddard, S. D.

Taub, J. M.

Taylor, J.

Wechsler, J. J. 
Oak Ridge Gaseous Diffusion Plant

Steif, S. S.

Wilcox, W. J., Jr

Oak Ridge National Laboratory

Weir, J. R., Jr

Oak Ridge Y-12 Plant

Alvey, H. E.

Armstrong, R. C.

Briscoe, O.W.

Burditt, R. B.

Carpenter, D. A.

Condon, J. B.

Dodson, W. H.

Duerksen, W. K.

Duggan, H. G.

Edwards, C. C.

Fraser, R. J.

Gritzner, V. B.

Holcombe, C. E. (15)

Hovis, V. M.

Hulsey. W. J.

Jones, F.W.

Kahl, K. G.

Kite, H. T.

Kite, H. T.

Long, P. J.

Marrow, G. B.

Mason, D. L.

Martin, W. R./Googin, J. M.

McLendon, J. D.

Mills, J. M., Jr

Phillips, L. R.

Rhew, J. E.

Rice, R. N.

Schrever. J. M.

Smith, H. F.. Jr

Smith, J. H.

Smith, R. D.

Smith, W. E.

Snyder, W. B.

Stoner, H. H.

Tewes, W. E.

Thompson, W. H., Jr

Townsend, A. B.

Weathersby, W. E.

Weber, G. W.
Williams, R. D.

Y-12 Central Files (master copy)

Y-12 Central Files (route copy)

$Y$-12 Central Files ( $Y$-12RC)

$Y-12$ Central Files (10)

Paducah Gaseous Diffusion Plant

Bewley; H. D.

Pennsylvania State University

Bradt, R. C.

Sandia - Albuquerque

Berry, L. M.

Bild, C. F.

Braasch, R. H.

Chabai, A. J.

Gardner, W. A.

Heilman, L. J.

Lang, J. J.

Mail Service Section

McDonald, J. E.

Peurifoy, R. L., Jr

Schuster, D. M.

Shuster, D. B.

Stroller, H. M.

Sandia - Livermore

Adolphson, D. R.

Barham, J. F:

Baroody, R. A.

Brandvold, G. E.

Brierly, J. M.

Gilson, J.

Gregson, D. E.

Kiny, J.C.

Marion, I. F. Meinken, R. $H$.

Technical Library

Union Carbide Corporation - New York

Chambers, W. E.

Winters, C.

University of Tennessee -

College of Engincering

Stansbury, E. E.

In addition, this report is distributed in accordance with the Category UC-25, Materials, as given in the USERDA Standard Distribution Lists for Unclassified Scientific and Technical Reports, TID-4500. 